Ornamented ModernにみるPicturesque につりて （特に庭園計画の内の poolとの関連方ら）

\title{
正会員 鈴木善市
}

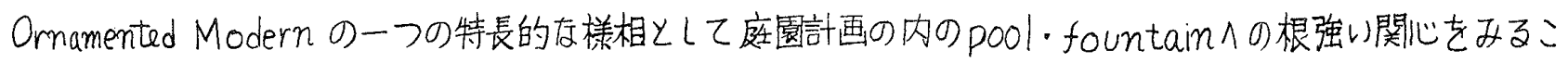
とガできる。例えが.Minoru Yamasaki の Wayne Univerity, E.D. Stone の Uniteds states Pavilion world's Fair Brussels 等はpool. fountainを作ることによって、建物の特っ内容と美を達成しているとみてよいであろう。 のような建物と Pool-fountain との建結はOmamented Modern特有のものであり、後期的特性の現わ炕でもある ○こでは、そのーつであるPicturesqueを建物とDool. fountainとの関建におりてとらえる。

picturesque の一特筫乙して遠像」の現象力ら多数的統一乙りうものがある。即5、architecturesque ガ全 く他に依疗世ずに独立して存在するのに反して、現象にあって反学辇性・反不明瞭性によるPicturesque は個及

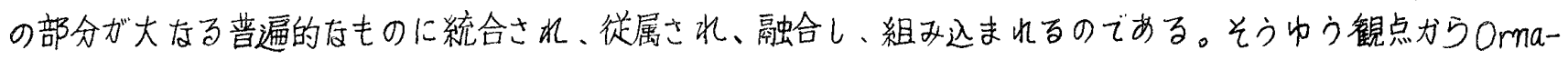
mented Modern几建物乙従属的度部分乙して庭園への建粘への根强り関心を見る:とができる。特に pool.fountainは自然感情、一種の清凉感等によって彼等の追求する概念と一致する所尤ら、常々用りられるものである。 この pool·fountainはO Ornamented Modern のロマンテイックな思潮にあってPicturesqueの橉相を表出する。 P o o lの太晹光裸の反射・建物の倒影・さざをみによる光之影の多粎さ、空の色の投影・刻刻乙变化する自然への

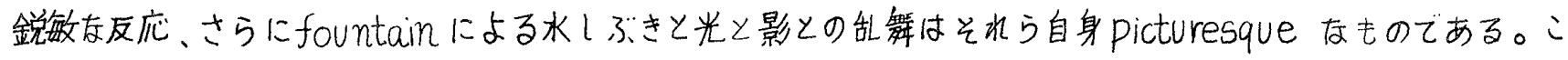
比ら不明瞭性、反单純性・偶然性过picturesqueの現象的特货である。

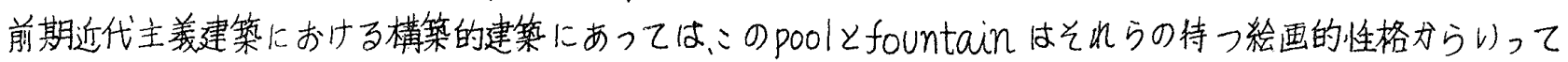
作ることの困難を施設てあるガ、MiesのBarcelonaの Pavillions にあけるpoolとの対比によって、Ornamented Modernのと冯が picturesqueであうとを一層設明しうるであろう。MiesのP ool 进物に対する從属的性

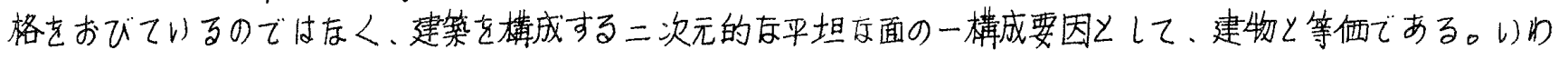

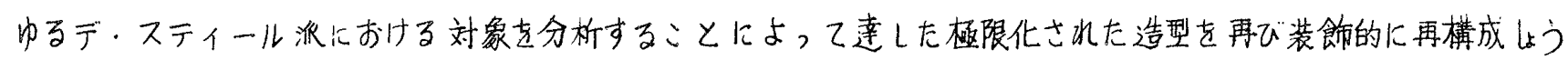
乙する。: てで抽象化の極限への指向から、不明瞭性、偶然性等の不確定要因术一切排除士れてりる。故に

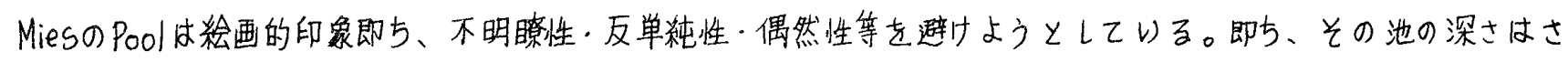

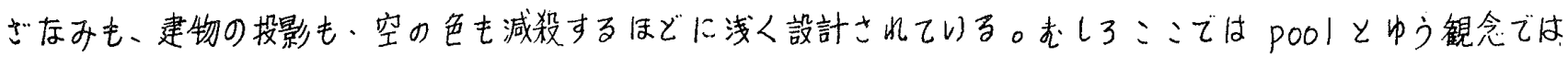

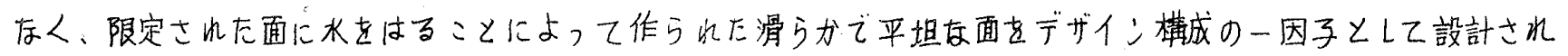
そりるのでる。屋根・天井・壁・床乙同橉にこのP D O l はデ・ステイル派の分析的精神による空間構成の一要因

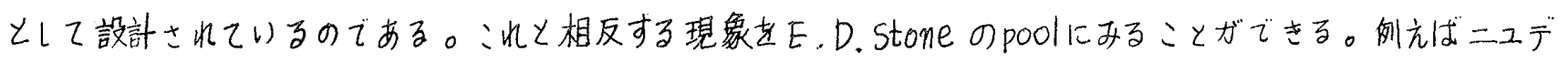

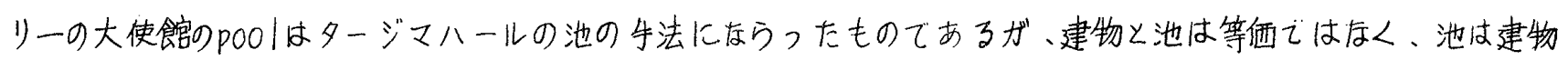

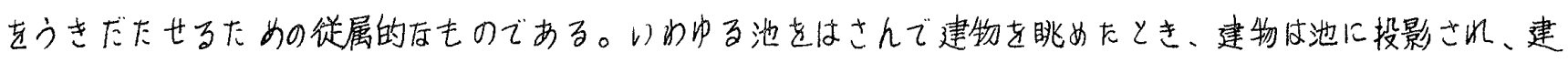

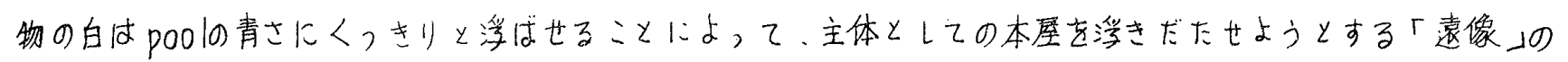

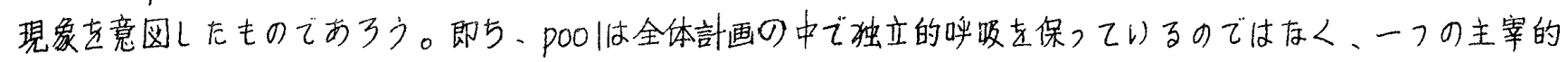

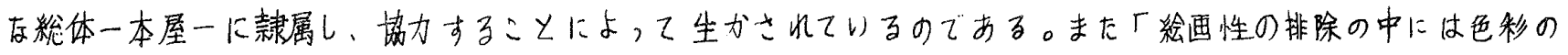

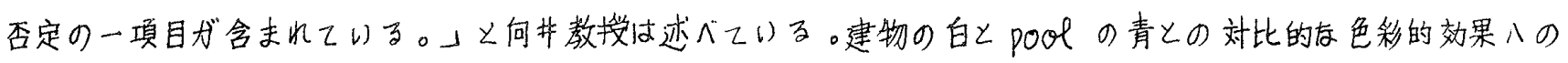

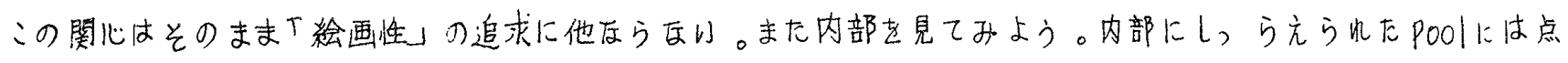

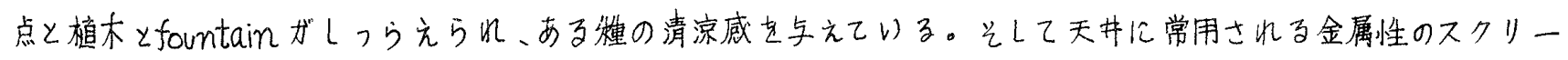

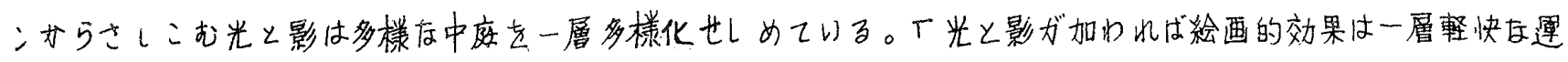

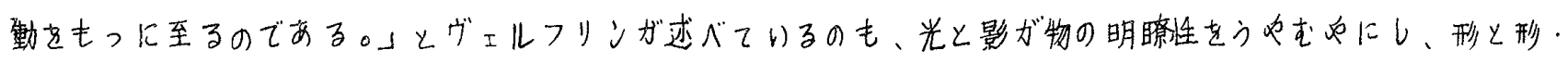

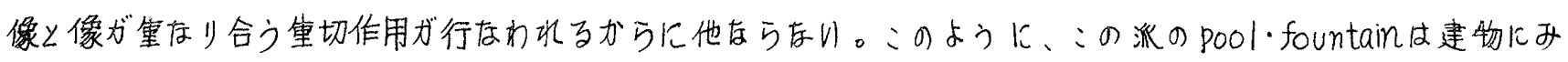
る Picturesqueを一層picturesqueにさすに適切应法をもって演出されているのて西る。

( 陴户大学院生) 